\title{
Effect of acarbose on glucose homeostasis, lipogenesis and lipogenic enzyme gene expression in adipose tissue of weaned rats
}

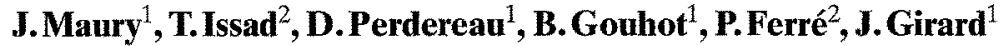 \\ ${ }^{1}$ Centre de Recherche sur l'Endocrinologie Moléculaire, et le Développement CNRS, Meudon, France \\ ${ }^{2}$ Unité 342 INSERM, Hôpital Saint Vincent de Paul, Paris, France
}

\begin{abstract}
Summary. Acarbose is a potent intestinal glucosidase inhibitor which could have an anti-obesity property by reducing postprandial plasma glucose and insulin levels, potentially responsible for high rates of lipid synthesis in adipose tissue. We have tested this hypothesis by studying rats during the weaning period, when the lipogenic capacity of the adipose tissue develops. Rats were treated from age 19 days onwards with acarbose $(10 \mathrm{mg} / 100 \mathrm{~g}$ diet $)$ and studied at age 30 days. Acarbose was efficient in reducing postprandial excursions of both blood glucose and plasma insulin. Acarbose-treated rats behave like rats continuously infused with glucose with no metabolic signs of carbohydrate deprivation since gluconeogenesis was not activated. There was no massive caecal fermentation of carbohydrate since volatile fatty acids did not significantly increase in the portal blood. One of the most
\end{abstract}

striking features of the acarbose-treated rats was the reduction of adipose tissue weight due to a reduced adipocyte size. This was concomitant with a reduced lipogenic capacity from glucose in isolated adipocytes under insulin stimulation. The activity of fatty acid synthase and acetyl-CoA carboxylase was decreased concomitantly with a reduced expression of their specific mRNA. This study allows the conclusion that postprandial hyperinsulinaemia and hyperglycaemia have a major role in the control of expression of lipogenic enzymes and thus on adipose tissue lipogenic capacity.

Key words: $\alpha$-Glucosidase inhibitor, glucose absorption, gluconeogenesis, plasma insulin, isolated adipocytes, lipogenesis.
$\alpha$-Glucoside hydrolases are key enzymes of carbohydrate digestion [1]. Acarbose is a potent intestinal glucosidase inhibitor with excellent affinity for sucrase, glucoamylase and maltase [2-4]. By its anti-sucrase and anti-maltase properties, acarbose reduces the availability of glucose for intestinal absorption, delays starch digestion and reduces postprandial plasma glucose and insulin levels in normal subjects $[1,5]$. Such modulation of the absorptive pattern of carbohydrates and resulting insulin secretion could be considered as an adjunct to specific therapy such as in diabetes. Indeed, acarbose is efficient in reducing postprandial plasma glucose and insulin levels in diabetic subjects $[6,7]$ and in non-diabetic and diabetic rats fed with a carbohydrate diet containing this inhibitor $[4,8]$. Similarly, acarbose could also be efficient in obesity by decreasing plasma insulin levels since metabolic abnormalities can be partly ascribed to hyperinsulinaemia [9].

During the suckling period, which corresponds to a high-fat low-carbohydrate diet, the lipogenic capacity in basal conditions or after stimulation by insulin is very low in white adipose tissue and it considerably increases after weaning to a high-carbohydrate diet. Indeed it has been shown that weaning to a high-carbohydrate diet is followed by a rapid increase in lipogenic enzyme mRNA and activities [10]. These results suggest that the appearance of peaks of plasma glucose and insulin concentrations concomitant with the adult high-carbohydrate meals may be involved in the development of the lipogenic capacity observed in white adipose tissue. Thus, the sucklingweaning transition is a good model with which to study whether acarbose, by its anti-hyperglycaemic and anti-hyperinsulinaemic properties, affects the development of the lipogenic capacity of white adipose tissue. We have thus addressed the following questions: is it possible to use acarbose in weaned rats to slow down glucose absorption? Has it any consequence on the metabolism of white adipose tissue?

\section{Materials and methods}

Chemicals: Acarbose was a gift of Bayer Laboratories (Wüppertal, FRG). Collagenase (0.44 U/mg) and chemicals for enzyme assays were from Boehringer Mannheim (Meylan, France). Phenol, chloroform, and ethanol were from Farmitalia (Carlo Erba, Milan, 
Italy). Formamide (deionized before use by treatment with Bio-Rad AG 501-X8 resin), formaldehyde, and pentanol-2 [isoamyl alcohol (IAA)] were from Prolabo (Paris, France). Dextran sulphate, agarose and serum bovine albumin fraction $V$ fatty acid-free (BSA) were purchased from Sigma (St Louis, Mo., USA). Nylon Hybond-N filters, multiprime DNA labelling system, $\left[\alpha{ }^{32} \mathrm{P}\right] \mathrm{dCTP}$ (specific activity $3,000 \mathrm{Ci} / \mathrm{mmol}$ ), and hyperfilms MP were supplied by Amersham International (Amersham, Bucks, UK) $\left[3{ }^{3} \mathrm{H}\right]$ glucose, [U$\left.{ }^{14} \mathrm{C}\right]$ glucose, and $\mathrm{NaH}\left[{ }^{14} \mathrm{C}\right] \mathrm{CO}_{3}$ were from the CEA (Gif-sur-Yvette, France).

Animals: Wistar rats bred in our laboratory were used. They were housed in a room in which the temperature was maintained at $24^{\circ} \mathrm{C}$, with light from 07.00 to 19.00 hours. The studies were performed on 14/15-day-old suckling rats, and on 28/32 day-old rats weaned at 19 days to a high carbohydrate (HC) diet (\% of energy: $62 \%$ carbohydrate, $12 \%$ fat and $26 \%$ protein) with or without acarbose.

In order to assess the most efficient dose of acarbose, a group of rats (24/25-day-old) was anaesthetized with pentobarbital $(1.3 \mathrm{mg} / \mathrm{g}$ body weight). Rats were then force-fed with $20 \mathrm{mg} / \mathrm{g}$ body weight of a carbohydrate mixture containing sucrose and raw starch (1/5 weight/weight) and 0,5 or $20 \mathrm{mg}$ acarbose $100 \mathrm{~g}$ of carbohydrate. Blood was sampled at different times after the gavage and blood glucose concentration was measured. Blood glucose and plasma insulin concentrations were also measured at $0,20,40$ and 60 min after a spontaneous meal in 23-day-old rats, fasted for $12 \mathrm{~h}$ and treated or not treated with acarbose from 19 days of age.

In order to evaluate the importance of gluconeogenesis for glucose homeostasis, anaesthetized 30-day-old weaned rats treated or not treated with acarbose were injected with 3-mercaptopicolinate (3-MPA) (75 mg/kg i.p.), a specific inhibitor of the key enzyme of gluconeogenesis, phosphoenolpyruvate carboxykinase (PEPCK) (EC. 41.1.32), at the end of the absorptive period (07.00 hours). The blood glucose concentration was followed for $60 \mathrm{~min}$ after the drug injection.

The adipose tissue from the dorsolumbar and pericardiac regions was dissected out as described by Pond and Mattacks and by Cantu and Goodman $[11,12]$, and was immediately weighed.

\section{Analytical techniques}

Blood glucose: Blood samples were treated as described previously [13], and blood glucose was measured by the glucose oxidase method (kit from Boehringer Mannheim).

Plasma insulin: Blood samples were treated as described previously [10] and plasma insulin was determined using a radioimmunoassay kit from Oris Industrie (Gif-sur-Yvette, France).

Lactate and volatile fatty acid concentrations: Lactate was determined spectrophotometrically at the end of the absorptive period and $6 \mathrm{~h}$ after food removal. Volatile fatty acids (acetate, butyrate and propionate) were determined by gas-liquid chromatography after ethanol extractions of samples according to Demigné et al. [14].

Glucose metabolism in isolated adipocytes: The subcutaneous white adipose tissue of the inguinal region was removed, cut into small pieces, and digested with collagenase. Krebs-Ringer phosphate buffer containing $1 \mathrm{mmol} / \mathrm{l}$ calcium was used for the digestion of adipose tissue which was performed in a shaking water-bath $\left(37^{\circ} \mathrm{C}\right)$ during $1 \mathrm{~h}$ under oxygenation $\left(\mathrm{O}_{2} / \mathrm{CO}_{2}, 95 / 5 \%\right)$. The digested tissue was then filtered through a 200 - $\mathrm{mm}$ nylon mesh, washed 3 times with the incubation buffer containing $1 \mathrm{mmol} / \mathrm{l}$ calcium and resuspended in the same buffer containing $2 \mathrm{mmol} / \mathrm{l}$ calcium. A sample of the initial cell suspension was used for the determination of cell concentration with a Neubauer haemocytometer. Mean fat-cell diameter was determined on four different preparations in each group (200300 cells in each preparation) using a photomicrographic method. The cells were incubated for $2 \mathrm{~h}$ in a shaking water-bath $\left(37^{\circ} \mathrm{C}\right)$ with different concentrations of insulin. $\left[\mathrm{U}^{14} \mathrm{C}\right]$ Glucose conversion into $\mathrm{CO}_{2}$, acylglycerol fatty acids and acylglycerol glycerol was deter- mined as described by Issad et al [13]. [U- $\left.{ }^{14} \mathrm{C}\right]$ Glucose conversion into lactate was determined as described by Ferré et al. [15].

Enzymes activities: The activity of fatty acid synthase (FAS) (EC 2.3.1.85) was determined with the spectrophotometric assay of Linn [16]. The results were expressed as nanomoles of NADPH oxidized per min per milligram of protein. The maximal activity of acetylCoA carboxylase (ACC) (EC 6.4.1.2) was determined according to Maeda et al. [17] after incubation in the presence of $10 \mathrm{mmol} / \mathrm{ci}$ trate, by the incorporation of $\mathrm{NaH}\left[{ }^{14} \mathrm{C}\right] \mathrm{CO}_{3}$ into malonyl-CoA. The results were expressed as nanomoles of malonyl-CoA formed per min per milligram of protein. The activity of PEPCK was measured by the method of Chang and Lane [18]. The results were expressed as nanomoles of $\mathrm{NaH}\left[{ }^{14} \mathrm{C}\right] \mathrm{CO}_{3}$ fixed per min per milligram of protein.

Total RNA extraction: Total cellular RNA was extracted from the subcutaneous adipose tissue of the inguinal region, using the hotphenol procedure of Scherrer and Darnell [19]. The concentration of RNA was determined by absorbance at $260 \mathrm{~nm}$, and the RNA solutions were stored in water at $-80^{\circ} \mathrm{C}$ until use. The integrity of RNA was systematically checked by electrophoresis in $0.8 \%$ agarose submarine minigel with ethidium bromide and visualized under ultraviolet fluorescence.

Dot-blot analysis of total RNA: The dot-blot procedure was used for relative quantification of specific mRNA concentration. Increasing amounts $(0.4-3 \mu \mathrm{g})$ of each total RNA sample to be analysed were denaturated by heating for $10 \mathrm{~min}$ at $65^{\circ} \mathrm{C}$, then directly dotted to a nylon membrane using a 96-hole Minifold apparatus (Schleicher\&Schuell, Dassel, FRG), and rinsed out twice with $20 \times$ sodium saline citrate (SSC). RNA was then fixed to the membrane by ultraviolet irradiation for $10 \mathrm{~min}$. The filters were kept at $4^{\circ} \mathrm{C}$ until hybridization.

Dot-blot hybridization: The pFAS 18 cDNA for rat liver FAS mRNA was obtained from Dr. A. G. Goodridge (Iowa City, Iowa, USA). The p181-6 cDNA for rat mammary gland ACC mRNA was obtained from Dr.K.H.Kim (West Lafayette, Ind., USA). Hybridizations to the labelled probes were performed in solutions containing $42 \%$ deionized formamide, $7.5 \%$ dextran sulphate, $8 \times$ Denhardt's solution, $40 \mathrm{mmol} / 1$ Tris $\mathrm{HCl}\left(\mathrm{pH} 7.5\right.$ )and $1 \%$ SDS at $42^{\circ} \mathrm{C}$ overnight. The membranes were washed twice for $30 \mathrm{~min}$ with $2 \times \mathrm{SSC} 0.1 \%$ SDS at $42^{\circ} \mathrm{C}$, and once for $30 \mathrm{~min}$ with $1 \mathrm{SSC} 0.1 \mathrm{SDS}$ at $65^{\circ} \mathrm{C}$ and exposed to Hyperfilm MP for $24-48 \mathrm{~h}$ at $-80^{\circ} \mathrm{C}$ with intensifying screens. Quantification was performed by scanning densitometry. Quantification was linear from 0.4 to $1.5 \mu \mathrm{g}$ of total RNA. The densitometric value corresponding to $1.5 \mu \mathrm{g}$ RNA was used for the results shown.

The specificity of the various cDNA probes as well as the validity of the dot-blot procedure for mRNA quantification have been previously checked by Northern blot analysis $[10,20,21]$.

\section{Statistical analysis}

Results are expressed as means \pm SEM. Statistical analysis was performed by Student's $t$-test for unpaired data or by analysis of variance $(F$-test) when necessary.

\section{Results}

\section{Efficiency of acarbose on glucose absorption in weaned rats}

Since acarbose has never been used in weaned rats, we checked whether it efficiently reduces postprandial excursions of blood glucose after a carbohydrate meal. In adult rats and mice, acarbose was effective at 20 and 


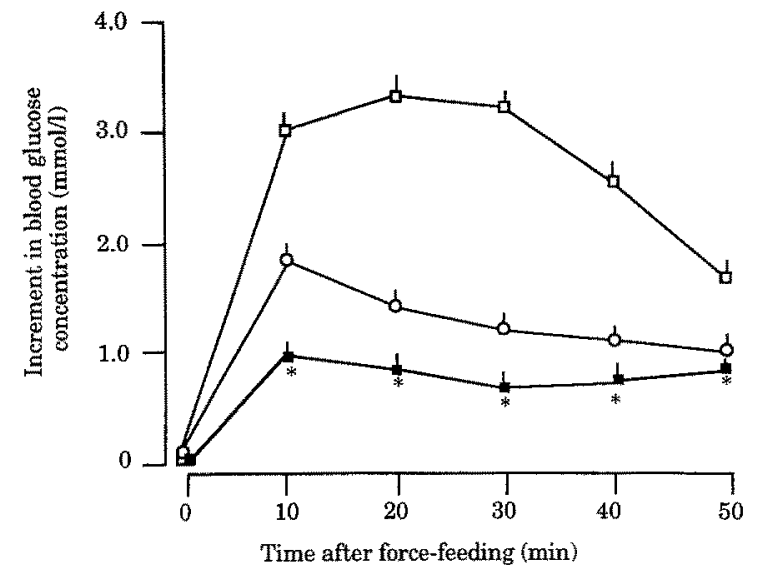

Fig.1. Effect of acarbose on blood glucose concentration after carbohydrate force-feeding. Rats (24/25-day-old) were anaesthetized and force fed with a carbohydrate mixture $(20 \mathrm{mg} / \mathrm{g}$ body weight) and different dosages of acarbose. Blood glucose concentration was measured every $10 \mathrm{~min}$ for $50 \mathrm{~min}$ after the force feeding. ( $\square$ ) Controls, (O) $5 \mathrm{mg} / 100 \mathrm{~g}$ acarbose in the diet, ( $) 20 \mathrm{mg} / 100 \mathrm{~g}$ acarbose in the diet. Each point is the mean $\pm S E M$ of four different rats. Statistically significant difference ( $F$-test) for $* p<0.05$ between controls and acarbose-treated rats

$40 \mathrm{mg} / 100 \mathrm{~g}$ chow $[4,22,23]$. In the present experiments, we used acarbose at 5 and $20 \mathrm{mg} / 100 \mathrm{~g}$ of diet, and blood glucose was determined at different times after force feeding 24/25-day-old rats with carbohydrates. Acarbose was efficient at significantly reducing the postprandial excursion of glycaemia at a dosage over $5 \mathrm{mg} / 100 \mathrm{~g}$ diet (Fig. 1 ). The next step was to find the dosage which to a lesser extent affected the growth and welfare of the rats. The food intake was measured every day from day 19 to day 30 in acarbose-treated rats $(5,10 \mathrm{and} 20 \mathrm{mg} / 100 \mathrm{~g}$ of diet $)$ and in the control group. No significant difference in the food intake was observed, whatever the dosage of acarbose used (mean food intake measured over 9 days was: $7.1 \pm$ $0.2 \mathrm{~g} /$ day in control rats $(n=9) ; 6.6 \pm 0.4 \mathrm{~g} /$ day in acarbose-treated rats $5 \mathrm{mg} / 100 \mathrm{~g} \operatorname{diet}(n=9) ; 7.2 \pm 0.4 \mathrm{~g} /$ day in acarbose-treated rats $10 \mathrm{mg} / 100 \mathrm{~g}$ diet $(n=9)$; and $6.9 \pm 0.6 \mathrm{~g} /$ day in acarbose-treated rats $20 \mathrm{mg} / 100 \mathrm{~g}$ dict $(n=9)$. The body weight of weaned rats was significantly reduced only at $20 \mathrm{mg}$ acarbose $/ 100 \mathrm{~g}$ diet (Table 1 ).
Liver, heart and various fat depots of 30-day-old rats were weighed. Body weight, liver and heart weight were significantly reduced at $20 \mathrm{mg}$ acarbose. Adipose tissue weight was affected at a smaller dosage of acarbose (Table 1).

\section{Effect of acarbose on blood glucose and plasma insulin concentrations after a spontaneous meal and during a 12-h fast in weaned rats}

In order to know the extent to which the dosage of acarbose used $(10 \mathrm{mg} / 100 \mathrm{~g}$ diet) reduced postprandial glycaemia and insulinaemia under physiological conditions, we measured these parameters in 23-day-old rats treated or not treated with acarbose from 19 days, after a spontaneous meal and after a 12-h fast. In acarbose-treated rats, glycaemia and insulinaemia increase only marginally after ingestion of the meal (Fig. 2). Moreover, after a 12-h fast, basal glycaemia and basal insulinaemia were 1.8 -fold higher in acarbose-treated rats. Indeed, blood glucose and plasma insulin concentrations at 0,6 or $12 \mathrm{~h}$ after food removal decreased continuously during the 12 - $\mathrm{h}$ fast in the control rats but remained unchanged in acarbose-treated rats (Fig.2).

\section{Fermentation products in acarbose-treated rats}

In order to determine if carbohydrate fermentation in the colon provides volatile fatty acids (butyrate, propionate, acetate), their concentrations were determined in the portal blood of post-absorptive rats. Volatile fatty acids were not significantly higher in acarbose-treated rats than in control rats (results not shown).

\section{Is hepatic gluconeogenesis stimulated by the acarbose treatment?}

If acarbose induces marked reductions in the amount of glucose absorbed, gluconeogenesis should be activated in acarbose-treated rats. This hypothesis was tested by using 3-MPA, an inhibitor of PEPCK, at the end of the absorp-

Table 1. Body weight and organ weight of rats treated or not treated with various dosages of acarbose

\begin{tabular}{|c|c|c|c|c|c|c|}
\hline \multicolumn{7}{|l|}{ Rats } \\
\hline \multirow{2}{*}{$\begin{array}{l}\text { Acarbose dosage } \\
(\mathrm{mg} / 100 \mathrm{~g} \text { diet })\end{array}$} & \multicolumn{2}{|l|}{5} & \multicolumn{2}{|l|}{10} & \multicolumn{2}{|l|}{20} \\
\hline & $\begin{array}{l}\text { Control } \\
4 \\
\end{array}$ & $\begin{array}{l}\text { Acarbose } \\
4\end{array}$ & $\begin{array}{l}\text { Control } \\
4 \\
\end{array}$ & $\begin{array}{l}\text { Acarbose } \\
4\end{array}$ & $\begin{array}{l}\text { Control } \\
4 \\
\end{array}$ & $\begin{array}{l}\text { Acarbose } \\
4\end{array}$ \\
\hline Body weight $(g)$ & $81 \pm 2$ & $75 \pm 2$ & $79 \pm 4$ & $73 \pm 3$ & $75 \pm 3$ & $62 \pm 4^{a}$ \\
\hline $\begin{array}{l}\text { Adipose tissue }(\mathrm{mg} \\
\text { Inguinal } \\
\text { Dorso-Lombar } \\
\text { Pericardiac }\end{array}$ & $\begin{array}{r}30 \pm 10 \\
228 \pm 10 \\
352 \pm 25\end{array}$ & $\begin{array}{l}33 \pm 6 \\
113 \pm 20^{a} \\
270 \pm 5\end{array}$ & $\begin{array}{c}48 \pm 4 \\
205 \pm 37 \\
300 \pm 22\end{array}$ & $\begin{array}{c}28 \pm 5^{\mathrm{a}} \\
118 \pm 25^{\mathrm{a}} \\
257 \pm 38\end{array}$ & $\begin{array}{c}32 \pm 5 \\
153 \pm 34 \\
263 \pm 17\end{array}$ & $\begin{array}{c}22 \pm 3^{a} \\
41 \pm 7^{a} \\
183 \pm 19^{a}\end{array}$ \\
\hline Heart (mg) & $357 \pm 25$ & $326 \pm 35$ & $335 \pm 25$ & $279 \pm 14$ & $327 \pm 12$ & $227 \pm 12^{\mathrm{a}}$ \\
\hline Liver $(g)$ & $3.3 \pm 0.1$ & $2.9 \pm 0.1$ & $2.9 \pm 0.2$ & $2.8 \pm 0.2$ & $2.9 \pm 0.1$ & $2.0 \pm 0.2^{a}$ \\
\hline
\end{tabular}

Rats were weaned at 19 days. Each rat in the acarbose-treated group was paired with a control of the same weight in the same litter. Body weight and organ weight were measured at 30 days. Results are the mean \pm SEM of four determinations. ${ }^{a} p<0.05$ between control and acarbose-treated rats $(t$-test) 

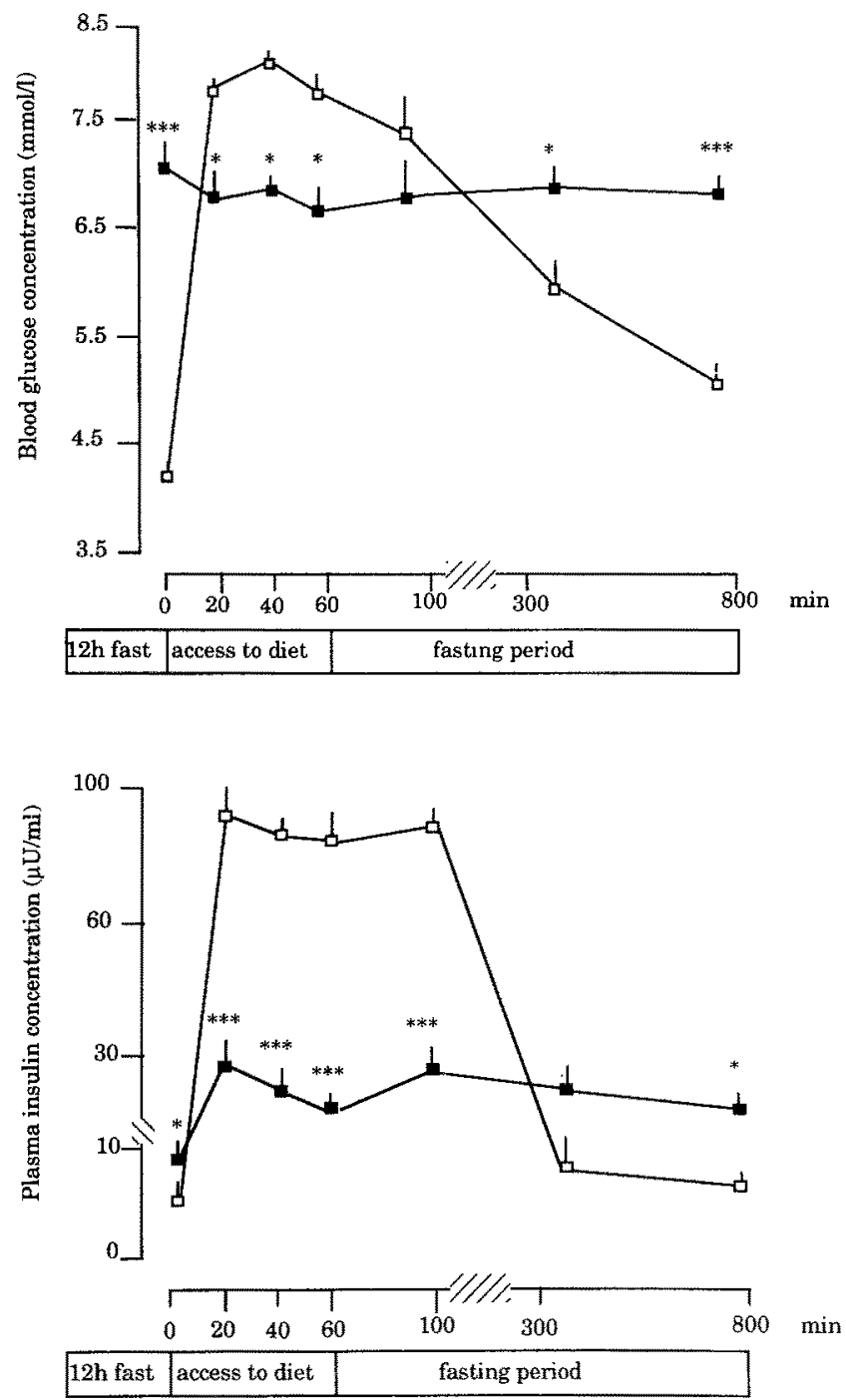

Fig. 2. Effect of acarbose treatment on glycaemia and insulinaemia during a 12-h fast and after a spontaneous meal in 23-day-old rats. Rats were treated or not with acarbose $(10 \mathrm{mg} / 100 \mathrm{~g}$ diet $)$ from 19 days. Blood glucose and plasma insulin concentrations were measured during a 12-h fast and after a normal diet meal. ( $\square$ ) Controls, ( ) acarbose-treated $(10 \mathrm{mg} / 100 \mathrm{~g}$ diet $)$. Each point is the mean \pm SEM of four different rats. Statistically significant difference $(F$ test) respectively for $* p<0.05$ and $* * * * 00.01$ between controls and acarbose-treated rats

tive period. 3-MPA induced an important hypoglycaemic effect in control rats fasted for $24 \mathrm{~h}$ (Fig. 3). In contrast, 3MPA did not significantly decrease blood glucose concentration in fed control rats and acarbose-treated rats. We completed this experiment by measuring the activity of PEPCK in control and acarbose-treated rats after sampling the liver of the rats at the end of the absorptive period. The activity of liver PEPCK was similar in control and acarbose-treated rats $(126 \pm 50, n=4$ vs $163 \pm$ $50 \mathrm{nmol} \times \min ^{-1} \times \mathrm{g}^{-1}$ of liver, $\left.n=4\right)$.

From this set of experiments, we can conclude that acarbose indeed reduces the glycaemia and insulinaemia excursions following meals and that acarbose-treated rats behave like rats infused continuously with glucose with no metabolic signs of carbohydrate deprivation. The next

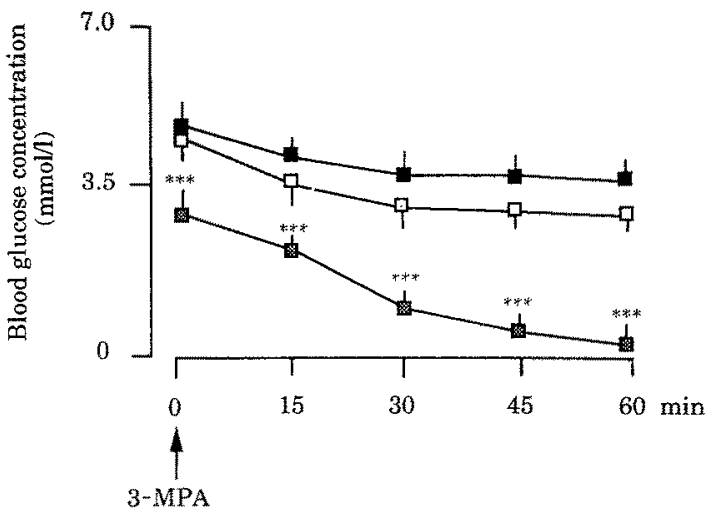

Fig. 3. Effect of 3-mercaptopicolinate (3-MPA), an inhibitor of gluconeogenesis, on blood glucose concentrations in absorptive rats. Rats treated or not treated with acarbose $(10 \mathrm{mg} / 100 \mathrm{~g}$ diet $)$ were injected with 3-MPA at the end of the absorptive period. A group of control rats was fasted for $24 \mathrm{~h}$ before the injection of 3-MPA. The pattern of blood glucose concentration was followed for $60 \mathrm{~min}$ after 3-MPA injection. (図) 24-h fasted controls, ( $\square$ ) fed controls, ( acarbose-treated $(10 \mathrm{mg} / 100 \mathrm{~g}$ diet $)$. Each point is the mean $\pm S E M$ of four different rats. Statistically significant difference $(F$-test $)$, respectively for $* * * 0,001$ between $24-\mathrm{h}$ fasted controls and the two other experimental groups

question was to assess whether it had an impact on adipose tissue metabolism.

\section{Fat pad weight and adipocyte size}

For this series of experiments the subcutaneous inguinal fat pad was sampled. As for other fat depots (Table 1), the fat pad weight was significantly lower in acarbose-treated rats than in controls, respectively $0.69 \pm 0.08 \mathrm{~g}$ vs $1.30 \pm 0.2 \mathrm{~g}(p<0.01)$, with a weight ratio control: acarbose of 1.93. In order to determine whether the weight reduction of adipose tissue was related to a decrease in the number or in the volume of adipose cells, adipocytes were isolated and the diameter of the adipocytes in each group was measured. The mean diameter of adipocytes was $56.6 \pm 0.6 \mu \mathrm{m}$ in control rats and $45.3 \pm 0.5 \mu \mathrm{m}$ in acarbose-treated rats $(p<0.001)$. From the measured mean diameter it is possible to calculate the mean volume of adipocytes in each group and the volume ratio control: acarbose. This ratio is 1.96 , which when compared with the weight ratio of 1.93 (see above) strongly suggests that it is the adipocyte volume and not the number per fat pad which is modified by the acarbose treatment.

\section{Glucose metabolism}

The products of glucose metabolism in isolated adipocytes are $\alpha$-glycerophosphate for the esterification of fatty acids to triglycerides, lactate released in the incubation medium, $\mathrm{CO}_{2}$ mainly derived from the decarboxylation of glucose into the pentose phosphate pathway and through the pyruvate dehydrogenase step and fatty acids of triacylglycerols. We studied the utilization of glucose in the various metabolic pathways in isolated adipocytes in the ab- 
Table 2. Utilization of glucose in isolated adipocytes in the absence or in the presence of insulin $(800 \mu \mathrm{U} / \mathrm{ml})$. Isolated adipocytes were prepared as described in Materials and methods section. The products of the various metabolic pathways were measured

\begin{tabular}{|c|c|c|c|c|}
\hline & \multirow{2}{*}{\multicolumn{2}{|c|}{$\begin{array}{l}\text { Controls } \\
n=4 \\
\text { Insulin }\end{array}$}} & \multirow{2}{*}{\multicolumn{2}{|c|}{$\begin{array}{l}\text { Acarbose } \\
n=4 \\
\text { Insulin }\end{array}$}} \\
\hline & & & & \\
\hline & Absence & Presence & Absence & Presence \\
\hline $\begin{array}{l}\text { Lactate production } \\
\left(\text { (nmol } \times 2 \mathrm{~h}^{-1} \times 10^{6} \text { cells }^{-1}\right)\end{array}$ & $151 \pm 43$ & $469 \pm 49$ & $227 \pm 53$ & $402 \pm 69$ \\
\hline $\begin{array}{l}\mathrm{CO}_{2} \text { production } \\
\quad\left(\text { nmol } \times 2 \mathrm{~h}^{-1} \times 10^{6} \text { cells }^{-1}\right)\end{array}$ & $77 \pm 19$ & $195 \pm 34$ & $57 \pm 16$ & $94 \pm 31^{\circ}$ \\
\hline $\begin{array}{l}\text { Incorporation into } \\
\alpha \text {-glycerophosphate } \\
\left(\text { nmol } \times 2 \mathrm{~h}^{-1} \times 10^{6} \text { cells }^{-1}\right)\end{array}$ & $48 \pm 6$ & $90 \pm 13$ & $53 \pm 6$ & $74 \pm 9$ \\
\hline $\begin{array}{l}\text { Incorporation into } \\
\text { fatty acids } \\
\left(\text { nmol } \times 2 \mathbf{h}^{-1} \times 10^{6} \text { cells }^{-1}\right)\end{array}$ & $45 \pm 9$ & $215 \pm 26$ & $29 \pm 17$ & $64 \pm 29^{\prime}$ \\
\hline
\end{tabular}

Results are the mean \pm SEM of four determinations. Difference significant ( $t$-test), respectively for ${ }^{\mathrm{a}} p<0.05$ and ${ }^{\mathrm{b}} p<0.001$ between control and acarbose-treated rats

sence or in the presence of $800 \mu \mathrm{U} / \mathrm{ml}$ insulin (Table 2). In control rats, insulin significantly increased the utilization of glucose in all the metabolic pathways. In the acarbosetreated group the stimulation of glucose utilization by in-

Fig.4. Lipogenic enzyme activities and mRNA concentrations in white adipose tissue of control ( $\boldsymbol{\omega})$ and acarbose-treated ( $\square$ ) rats. The activity of fatty acid synthase (FAS) and acetyl-CoA carboxylase (ACC) was determined in the subcutaneous inguinal fat pad. Total RNA of FAS, ACC of the same pads was extracted and dotblotted. The concentration of specific mRNA was analysed by hybridation with ${ }^{32} \mathrm{P}-1$ labelled cDNA probes. Results are the mean $\pm \mathrm{SEM}$ of five determinations. Statistically significant difference $(t$-test $)$, respectively for $* p<0.05$ and $* * p<0.01$ between controls and acarbose-treated rats sulin was lower. The main difference in adipocytes from acarbose-treated and control rats was found in the glucose oxidation and in the lipogenic capacity (incorporation of glucose into fatty acids) under insulin stimulation, leading to a decreased total glucose utilization in the adipocytes of acarbose-treated rats.

\section{Lipogenic enzyme activities and $m R N A$ concentrations}

We then measured the activities of the two major lipogenic enzymes, FAS and ACC in white adipose tissue. The activity of FAS and ACC were significantly lower in acarbose-treated rats $(n=6, p<0.01)$ (Fig. 4). A marked decrease in the relative concentration of FAS and ACC mRNAs was found in the acarbose-treated rats (2.4 and

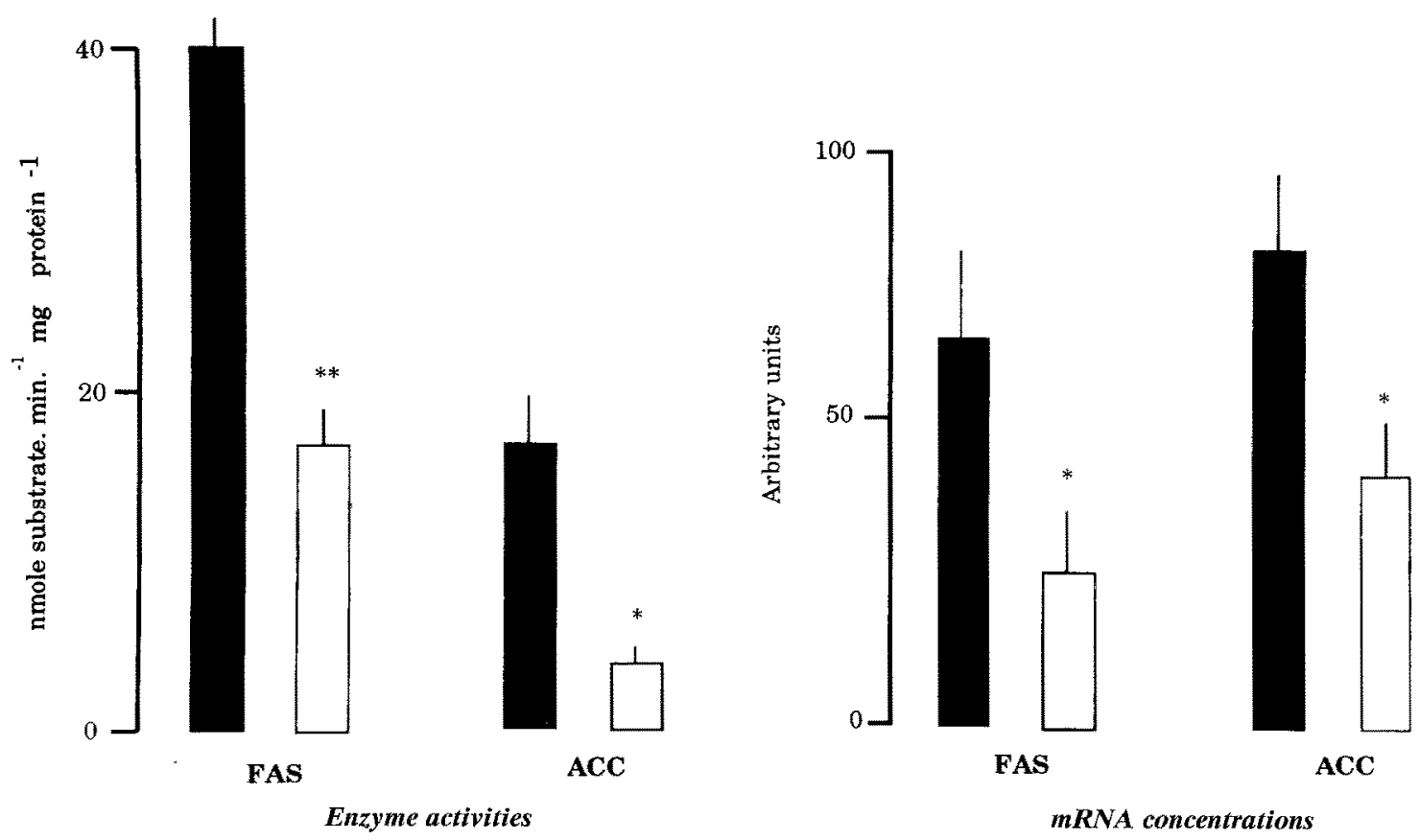


1.8-fold lower, respectively than in control rats, $p<0.05$ ) (Fig.4). In order to verify that these changes were specific for lipogenic enzymes, the blots were hybridized with the PEPCK CDNA probe since this enzyme changes in an opposite direction to that of lipogenic enzymes [10]. Between 21 days and 30 days, PEPCK mRNA concentration in white adipose tissue was decreased by $30 \pm 10 \%$ in acarbose-treated rats $(n=6)$ and by $70 \pm 5 \%$ in control rats $(n=6, p<0.01)$.

\section{Discussion}

In the present study, we have shown that acarbose is efficient in significantly reducing the meal-induced excursions of blood glucose and plasma insulin concentrations. This is in agreement with other studies in genetically obese animals $[24,25]$. Acarbose could reduce or slow down carbohydrate absorption or both from the gastrointestinal tract, as it has been shown in man in vivo where acarbose was able to decrease carbohydrate absorption by $30 \%$ and to increase the absorption time up to 1.7-fold in a dose-dependent fashion [26].

In our model, the main effect of acarbose seems to be a slowing down rather than an overall decrease of carbohydrate absorption. Indeed, very few products of carbohydrate caecal fermentations are found in the portal vein and gluconeogenesis is not increased in acarbose-treated rats. This was not unexpected, since in our study, weaned rats received a small dose of acarbose $(10 \mathrm{mg} / 100 \mathrm{~g}$ diet). Indeed, Puls and Bishoff [3] have shown that the increase of liver gluconeogenesis requires high doses ( $>150 \mathrm{mg} / 100 \mathrm{~g}$ diet) of acarbose and was due to the lack of alimentary carbohydrates, since undigested carbohydrates were excreted in faeces.

This series of experiments suggests that acarbose-treated rats behave like rats continuously perfused with glucose, due to the slowing-down of glucose absorption. This explains why their glycaemia is constant over a 12 -h fast and does not increase during the prandial period. We have thus firmly established a model in which the main alteration in carbohydrate homeostasis is the absence of blood glucose and plasma insulin peaks during meals.

This has clear effects on adipose tissue metabolism as shown by its weight reduction. The decreased lipogenic capacity probably contributes to the decreased adipose cell volume although a decreased lipoprotein lipase activity cannot be excluded. The observed effect is linked with a decreased gene expression of lipogenic enzymes and indicates a potential role for glucose and insulin excursions in the regulation of these genes as previously suggested [10].

This study confirms that hyperinsulinaemia and hyperglycaemia have a major role in the over-expression of lipogenic enzymes. This fits with in vitro studies [27] showing that glucose and insulin control FAS and ACC expression and with in vivo studies in obese animals in which hyperinsulinaemia is concomitant with increased glucose utilization and lipogenic capacity in white adipose tissue in the post-absorptive state [28-30]. Thus, reductions of hyperinsulinaemia and hyperglycaemia could be a rational treatment of genetic obesity.
Acknowledgements. This work was supported by grants from BayerPharma, France. We acknowledge Drs. H. Bischoff and O. Régnier for their interest and support during this study.

\section{References}

1. Caspary WF (1978) Sucrose malabsorption in man after ingestion of $\alpha$-glucoside hydrolase inhibitor. Lancet I: 1231-1233

2. Puls W, Keup U, Krause HP et al. (1980) Phamacology of a glucosidase inhibitor. Front Hormone Res 7: 235-247

3. Puls W, Bishoff H (1983) Pharmacology of amylase and glucosidase-inhibitors. In: Creutzfeldt W, Fölsch UR (eds) Delaying absorption as a therapeutic principle in metabolic disease. Thieme, Stuttgart New York, pp 70-78

4. Lee SM, Bustamante SA, Koldovsky O (1983) The effect of $\alpha$ glucosidase inhibition on intestinal disacharidase activity in normal and diabetic mice. Metabolism 32: 793-799

5. Keup U, Krause HP, Puls W, Thomas G (1982) Pharmacological studies on acarbose. I) Antihyperglycemic effects. In: Creutzfeldt W (ed) First International Symposium on Acarbose. Excerpta Medica, Amsterdam, pp 147-150

6. Willms B, Sachse $G$, Unger H (1980) Treatment of diabetes with a glycoside hydrolase inhibitor (Acarbose, Bay g 5421). Front Hormone Res 7: 276-281

7. Reaven GM, Lardinois CM, Greenfield MS, Schwartz HC, Vreman HJ (1990) Effect of acarbose on carbohydrate and lipid metabolism in NIDDM patients poorly controlled by sulfonylureas. Diabetes Care 13:32-36

8. Gray SR, Olefsky MM (1982) Effect of a glucosidase inhibitor on the metabolic response of diabetic rats to a high carbohydrate diet, consisting of starch and sucrose, or glucose. Metabolism 31: $88-92$

9. Jeanrenaud B (1978) Hyperinsulinemia in obesity syndromes: its metabolic consequences and possible etiology. Metabolism 27: $1881-1892$

10. Coupé C, Perdereau D, Ferré P, Hitier Y, Narkewicz M, Girard J (1990) Lipogenic enzyme activities and mRNA in rat adipose tissue during weaning: role of the diet. Am J Physiol 258: E126E133

11. Pond CM, Mattacks CA (1991) The effects of noradrenaline and insulin on lipolysis in adipocytes isolated from nine different adipose depots of guinea-pigs. Int J Obesity 15: 609-618

12. Cantu RC, Goodman HM (1967) Effects of denervation and fasting on white adipose tissue. Am J Physiol 212: 207-212

13. Issad T, Coupé C, Pastor-Anglada M, Ferré P, Girard J (1988) Development of insulin-sensitivity at weaning in the rat. Role of the nutritional transition. Biochem J 251: 685-690

14. Demigné C, Yacoub C, Rémésy C (1986) Effects of absorption of large amounts of volatile fatty acids on rat liver metabolism. $\mathbf{J}$ Nutr 116: 77-86

15. Ferré P, Pégorier JP, Marliss EB, Girard J (1978) Influence of exogenous fat and gluconeogenic substrates on glucose homeostasis in the newborn rat. Am J Physiol 234: E129-E136

16. Linn TC (1981) Purification and crystallization of rat liver fatty acid synthetase. Arch Biochem Biophys 209:613-619

17. Maeda H, lkeda I, Sugano M (1975) Behavior of the liver key lipogenesis enzymes in rat fed with threonine imbalanced diet. Nutr Rep Int 12: 61-66

18. Chang HC, Lane MD (1966) Purification and properties of liver mitochondrial phosphoenol pyruvate carboxykinase. J Biol Chem 241:2413-2420

19. Scherrer K, Darnell J (1962) Sedimentation characteristics of rapidly labelled RNA from HeLa cells. Biochem Biophys Res Commun 7: 486-490

20. Leturque A, Postic C, Ferré P, Girard J (1991) Nutritional regulation of glucose transporter in muscle and adipose tissue of weaned rats. Am J Physiol 260: E588-E593

21. Foufelle F, Perdereau D, Gouhot B, Ferré P, Girard J (1992) Effect of diets rich in medium-chain and long-chain triglycerides on 
lipogenic-enzyme gene expression in liver and adipose tissue of the weaned rat. Eur J Biochem 208: 381-387

22. Koevary SB (1990) Effects of acarbose on the development of diabetes in BB/Wor rats. Metabolism 39: 865-870

23. Katovich MJ, Meldrum MJ, Vasselli JR (1991) Beneficial effects of dietary acarbose in the streptozotocin-induced diabetic rat. Metabolism 40: 1275-1282

24. Vasselli JR; Haraczkiewicz E, Maggio CA, Greenwood MRC (1983) Effect of an alpha-glucosidase inhibitor (Acarbose BAY g 5421 ) on the development of obesity and food motivated behavior in Zucker ( $\mathrm{fa}$ fa) rats. Pharmacol Biochem Behavior 19: 8589

25. Le Marchand-Brustel Y, Rochet N, Grémeaux T, Marot I, Van Obberghen E (1990) Effect of an $\alpha$-glucosidase inhibitor on experimentally-induced obesity in mice. Diabetologia 33: $24-30$

26. Radziuk J, Kemmer F, Morishima T, Berchtold P, Vranic M (1984) The effects of an alpha-glucoside hydrolase inhibitor on glycemia and the absorption of sucrose in man determined using a tracer method. Diabetes 33: 207-213

27. Foufelle F, Gouhot B, Pégorier P et al. (1992) Glucose stimulation of lipogenic enzyme gene expression in cultured white adipose tissue. J Biol Chem 267: 20543-20546
28. Pénicaud L, Ferré P, Terretaz J et al. (1987) Development of obesity in Zucker rats. Early insulin resistance in muscles but normal insulin sensitivity in white adipose tissue. Diabetes 36 : $626-631$

29. Krief S, Bazin R, Dupuy F, Lavau M (1988) Increased in vivo glucose utilization in 30-day-old obese Zucker rat: role of white adipose tissue. Am J Physiol 254: E342-E348

30. Pénicaud L, Ferré P, Assimacopoulos-Jeannet F et al. (1991) Increased gene expression of lipogenic enzymes and glucose transporter in white adipose tissue of suckling and weaned obese Zucker rats. Biochem J 279:303-308

Received: 11 September 1992

and in revised form: 19 February 1993

Dr.J.Girard

Centre de Recherche sur l'Endocrinologie

Moléculaire et le Développement CNRS

9 rue Jules Hetzel

F-92190 Meudon

France 